AperTO - Archivio Istituzionale Open Access dell'Università di Torino

\title{
Shelf-life extension of highbush blueberry using 1-methylcyclopropene stored under air and controlled atmosphere
}

\section{This is the author's manuscript}

Original Citation:

Availability:

This version is available http://hdl.handle.net/2318/85279

since

Published version:

DOI:10.1016/j.foodchem.2010.12.032

Terms of use:

Open Access

Anyone can freely access the full text of works made available as "Open Access". Works made available under a Creative Commons license can be used according to the terms and conditions of said license. Use of all other works requires consent of the right holder (author or publisher) if not exempted from copyright protection by the applicable law. 


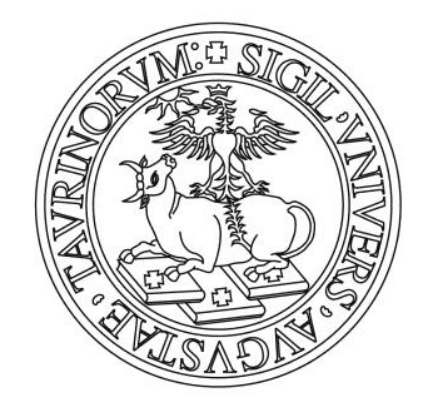

\section{UNIVERSITÀ DEGLI STUDI DI TORINO}

This is an author version of the contribution published on:

Questa è la versione dell'autore dell'opera:

[Food Chemistry, 126, 4, 2011, doi:10.1016/j.foodchem.2010.12.032]

The definitive version is available at:

La versione definitiva è disponibile alla URL:

[http://www.journals.elsevier.com/food-chemistry] 
Shelf-life extension of highbush blueberry using 1-methylcyclopropene stored under air and controlled atmosphere

Valentina Chiabrando*, Giovanna Giacalone

Dipartimento di Colture Arboree, Facoltà di Agraria, Università degli Studi di Torino Via Leonardo da Vinci 44, 10095, Grugliasco (TO), Italia

*Corresponding author. Tel +390116708938. Fax +390116708658. E-mail address: valentina.chiabrando@unito.it

\begin{abstract}
The potential of 1-Methylcyclopropene for controlling ripening in 'Lateblue' blueberry fruit was explored. After harvest, blueberry fruits were exposed in 1-MCP $\left(0.3\right.$ and $\left.0.6 \mu \mathrm{l}^{-1}\right)$. After treatment samples were stored in air at $0^{\circ} \mathrm{C}$ for 35 days and in Controlled Atmosphere $\left(3 \mathrm{kPa} \mathrm{O}_{2}+11 \mathrm{kPa} \mathrm{CO}_{2}\right)$ for 60 days. Quality parameters were monitored (weight loss, total soluble solid content, titratable acidity, firmness, anthocyanin contents, phenolic contents, total antioxidant capacity). Blueberries treated with 1-MCP showed a reduced weigth loss during storage and a lower total soluble solid content compared to untreated fruit. High titratable acidity values were observed after Controlled Atmosphere storage, but no significant effect of 1-MCP on this parameter was observed. 1-MCP had no significant effect on anthocyanin, phenolic and antioxidant activities.
\end{abstract}

Keywords: 1-Methylcyclopropene, anthocyanin contents, berry fruit, CA storage, Lateblue, phenolic contents, postharvest, quality, RA storage, total antioxidant capacity.

\title{
1. Introduction
}

1-Methylcyclopropene is an inhibitor of ethylene receptors that can affect ripening and senescence processes in fruit, vegetables and ornamental products (Sisler \& Serek 1997; Watkins \& Miller 2005). 1-MCP is classified as a plant growth regulator and induce beneficial effects, such as delay of the physico-chemical changes related to the ripening process, as well as a reduction of decay and softening in many fruit and vegetables such as apples, kiwifruit, peaches, nectarines, plums and pears (Bouquete, Trinchero, Fraschina, 
Vilella \& Sozzi, 2004; Liguori, Weksler, Zutahi, Lurie \& Kosto, 2004; Trinchero, Sozzi, Covatta \& Fraschina 2004; DeEll, Murr, Ehsani-Moghaddam, 2008). The safety, toxicity and environmental profiles of 1-MCP with regard to humans, animals and the environment are favourable. The compound is used at low rates, has a non-toxic mode of action and is chemically similar to naturally occurring substances (Blankenship and Dole, 2003).

Blueberries are highly perishable fruits and therefore it is necessary to develop strategies to increase their storage life. Storage trials using controlled atmosphere have indicated that shelf-life extension can be obtained for blueberries using combinations of elevated $\mathrm{CO}_{2}$ and reduced $\mathrm{O}_{2}$ during storage (Ceponis \& Cappellini, 1985; Smittle \& Miller, 1988). One of the major factors responsible for the short shelf life of blueberry fruit was the high weight loss that caused shrivelling and loss of brightness. Fruits weight loss is mainly due to water loss which is produced by a difference in vapor pressure between the fruits and surrounding air. This loss is affected by the area/volume relationship, mechanical wounds on the epidermis area, and storage temperature (Wills, McGlasson, Graham \& Joyce, 1998). Small-sized fruits such as blueberries show a high area/volume, therefore dehydrate more than larger-sized fruits (Wills et al., 1998; Cabezas, 2004; Navarrete, 2004).

To evaluate 1-MCP effectiveness on blueberry fruit, the change in fruit firmness, weight loss, soluble solids concentration and titratable acidity, as well as antioxidant activities, total phenolic and anthocyanin content, during long term storage in air and controlled atmosphere conditions, were determined. The possibility that 1-MCP can inhibit development Botrytis cinerea during postharvest storage period was also tested.

\section{Materials and methods}

\subsection{Fruit material}

A late season blueberry cultivar (Vaccinium corymbosum L. cv Lateblue) was used in this study. The berries were handharvested at the end of August in 2006 and 2007 at full maturity (100\% blue) in Peveragno (CN, Italy) into $250 \mathrm{~g}$ punnets and transported to the laboratory. Fruits were selected based on their uniformity of size and colour. Rotten and damaged fruits were eliminated. The punnets were immediately labelled, weighed and randomly assigned to each of the treatments. 


\section{$2.21-M C P$ treatments and storage conditions}

SmartFresh $^{\text {SM }}$ (1-MCP 0.14\%) was supplied by AgroFresh Inc. as a powder, that after addition of distilled water released the active ingredient as gas, according to the manufacturer's instructions. Different amounts of the powder were weighed and distilled water was added to obtain doses of 0.3 and $0.6 \mu 11^{-1}$.

Treatments were performed in $0.30 \mathrm{~m}^{3}$ hermetically sealed containers. Fruit were exposed to $0.3 \mu 11^{-1}$ (in 2006) and to 0.3 and $0.6 \mu \mathrm{l}^{-1}$ (in 2007) at $20^{\circ} \mathrm{C}$ for $24 \mathrm{~h}$ (Blankenship \& Dole, 2003). Control fruit were similarly treated but without 1-MCP.

After the treatment the fruits were stored under regular cold storage (RA) ( $0^{\circ} \mathrm{C}, 90-95 \%$ R.H.) for 35 days and under controlled atmosphere (CA) conditions $\left(0^{\circ} \mathrm{C}, 90-95 \%\right.$ R.H.; $\left.3 \mathrm{kPa} \mathrm{O}+11 \mathrm{kPa} \mathrm{CO}_{2}\right)$ for 60 days, technology of storage usually adopted for this kind of fruit in Italy.

\subsection{Quality evaluations}

Berry quality was assessed at harvest and weekly for Regular Atmosphere storage and after 60 days for Controlled Atmosphere storage.

Weight loss was determined by weighing the punnets at the start of the experiment ( 0 time) and at 7 days intervals during RA storage. Values are reported as percent of weight loss per initial fruit weight.

Total soluble solids content, $\mathrm{pH}$, and titratable acidity were measured using juice extracted from a 50g berry sample blended at high speed in a tissue homogenizer. Soluble solids concentration was determined by a digital refractometer (Atago refractometer model PR-32). Three measurements were taken on each sample and the results expressed as ${ }^{\circ}$ Brix.

Titratable acidity and $\mathrm{pH}$ were measured by titrating 1:10 diluted juice using $0.1 \mathrm{~N} \mathrm{NaOH}$ by an automatic titrator (Compact 44-00, Crison). This measurement was replicated three times for each tretments.

Firmness was measured on 30 individual fruit per treatment at the start of the experiment and at 7 days intervals using a nondestructive penetrometer test, Durofel ${ }^{\circledR}$ (Copa Technologie), a dynamometer with a bolt of $3 \mathrm{~mm} \varnothing\left(0.10 \mathrm{~cm}^{2}\right)$, on a scale of 1 (soft) to 100 (firm). Results were expressed as Durofel Index (D.I.). 


\subsection{Anthocyanin contents, phenolic contents, total antioxidant capacity}

For determination of the anthocyanin contents, phenolic contents and total antioxidant capacity, extracts were prepared by weighing $10 \mathrm{~g}$ of fresh berries into a centrifuge tube, adding methanol (25 $\mathrm{ml})$ and homogenising the sample for $1 \mathrm{~min}$. Extractions were performed under reduced light conditions. Tubes were centrifuged (3000 rpm for $15 \mathrm{~min}$ ) and the clear supernatant fluid collected and stored at $-26^{\circ} \mathrm{C}$.

For identification and quantification, extraction was performed as three replicates.

Anthocyanin content was quantified according to the $\mathrm{pH}$ differential method by Cheng and Breen (1991). Anthocyanins were estimated by their difference of absorbances at 510 and at $700 \mathrm{~nm}$ in buffer at $\mathrm{pH} 1.0$ and at $\mathrm{pH} 4.5$, where $\mathrm{A}=\left(\mathrm{A}_{515}-\mathrm{A}_{700}\right)_{\mathrm{pH} 1.0}-\left(\mathrm{A}_{515}-\mathrm{A}_{700}\right)_{\mathrm{pH} 4.5}$. Results were expressed as $\mathrm{mg}$ of cyanidin-3glucoside $(\mathrm{C} 3 \mathrm{G})$ per $100 \mathrm{~g}$ of fresh berries.

Total phenolics were determined with Folin-Ciocalteu reagent by the method of Slinkard and Singleton (1977) using gallic acid as a standard. Absorption was measured at $765 \mathrm{~nm}$. Results were expressed as mg gallic acid equivalents (GAE) per 100g of fresh berries.

Antioxidant activity was determined using ferric reducing antioxidant power (FRAP) assay, following the method by Pellegrini, Serafini, Colombi, Del Rio, Salvatora and Bianchi (2003) with some modifications. The antioxidant capacity of dilute berry extract is determined by its ability to reduce ferric iron to ferrous iron in a solution of TPTZ prepared in sodium acetate at $\mathrm{pH}$ 3.6. The reduction of iron in the TPTZ-ferric chloride solution (FRAP reagent) results in the formation of a blue-colored product (ferrous tripyridyltriazine complex), the absorbance of which is read spectrophotometrically at $593 \mathrm{~nm} 4 \mathrm{~min}$ after the addition of appropriately diluted berry extract or antioxidant standard to the FRAP reagent. Results were expressed as mmol Fe2+/kg of fresh berries.

\subsection{Decay incidence}


Berries were also scored for incidence of Botrytis cinerea. The loss of berries due to fungal growth was measured by weighing fruit with visible mycelium growth. The results were expressed as percentage of fruits infected by fungus. No discrimination was made on the basis of the level of decay.

\subsection{Statistical analysis}

Data were analyzed by analysis of variance using statistical procedures of the STATISTICA ver. 6.0 (Statsoft Inc., Tulsa, OK, USA). The sources of variance being 1-MCP treatments. Tukey's test HSP (honestly significant differences) was used to determine significant differences among treatment means. Means values were considered significantly different at $\mathrm{P} \leq 0.05$.

\section{Resuls and discussion}

\subsection{Weight loss}

In this study, the loss of weight progressively increased with storage time and was linear for all treatments (Table 1) and both years. In 2006 1-MCP treated samples showed slightly lower weight loss compared to control samples and the differences between treatments was significant after 14 days of storage (Table 1). In 2007, a significant effect of 1-MCP was observed only at day 7 and 21 with the highest 1-MCP concentration; at day 35 no effect was observed (Table 1).

\subsection{Quality attributes}

Results showed that total soluble solids content of the berries from the different treatments reacted in a similar way and was quite stable during storage in control and treated fruits (table 2). The trend in TSS over time coincides with what Miller, McDonald and Crocker (1988) informed in rabbiteye blueberry, Almenar, Samsudin, Auras, Harte and Rubino (2008) in highbush blueberry, and Hevia, Lanuza, Wilckens, Tello and Alvarez (2000) in red currant (Ribes rubrum L.). 
Total soluble solids content showed no coherent change during storage and between treatments. In 2006, in control samples soluble solid content increased during the first week of storage and than progressive decrease. In 1-MCP treated fruit TSS increased during 14 days if storage period. In 2007, at the end of storage, control berries had the highest soluble solids content. After CA storage, in 2006, no significant effect of 1-MCP on soluble solid was observed; in 2007, berries treated with low 1-MCP concentration had the highest total soluble solid values, and control berries the lowest. Delay in the increase of soluble solid content was reported for pears (Trinchero et al., 2004) and plums (Valero, Martinez-Romero, Valverde, Guillen, Castillo \& Serrano 2004); soluble solid content were unaffected by 1-MCP teatments in apricots and plums (Dong, Lurie \& Zhou, 2002).

When ethylene action was suppressed or reduced with the use od 1-MCP, expectedly, these

resulted in corresponding changes in maturity and quality parameters. A delay in softening, retention of green color, and reduction in acid degradation rate were observed and are representative of features that have previously been shown to be ethylene-dependent (Wang\& Dilley, 2001). On the other hand, another parameter, like TSS, was slightly affected by a reduction in ethylene action and can be considered an ethylene-independent parameter (Blankenship \& Sisler, 1989).

Titratable acidity (TA) increased during storage to a similar extent in all treatments. Changes in berry weight (up to 4\%) that occurred during the postharvest period may have influenced the values for titratable acidity; it is possible that a portion of the increase in this variable during storage was due to water loss (Colelli, D'Andria, Vanadio \& Lacertosa, 2002). Fruit dehydration provokes an acid concentration, and consequently shows a greater value in titratable acidity. An increase in acidity over time was observed in rabbiteye blueberry 'Woodard', Smittle and Miller (1988) which found an increase in acidity over time of $0.52 \%$ to 0.63\% in 21 days of storage at $5{ }^{\circ} \mathrm{C}$. Moreover Loyola, Aranda, Teixido and Palma (1996) found an increase in acidity starting on storage day 7 at $0{ }^{\circ} \mathrm{C}$, with values varying from $0.64 \%$ to $0.85 \%$ in highbush blueberry 'Blueray'.

In 2006, during short term cold storage (2-3 weeks) titratable acidity was significantly higher for 1-MCP fruit than for control fruit. This is probabily due because the protective effect of 1-MCP, inhibiting the 
action of ethylene, reduces the respiratory activity and, consequently, reduces the catabolism of organic acids (Girardi, Corrent, Lucchetta, Zanuzo

Da Costa, Brackmann, Twymand, Nora, Nora, Silva \& Rombaldi, 2005). No significant differences in titratable acidity were observed between control (164.71 meq/l) and 1-MCP treated fruit (137.2 meq/l) after medium-term cold storage (5 weeks) (Table 2). The same effects, at the end of storage period, were observed in 2007 (Table 2).

After 60 days of CA storage, high titratable acidity values were observed, but no significant differences were observed between control and 1-MCP treated fruits according with the results of Dong et al. (2002) and Trinchero et al. (2004) in apples and pears. In contrast, titratable acidity loss was significantly delayed or maintained by 1-MCP in plums (Fan, Blankenship \& Mattheis, 1999). These differences in effectiveness of 1-MCP on quality parameters may be due to the different behavior of the fruits, maturity stage or other experimental conditions as suggested by Blankenship and Dole (2003).

Fruit firmness increased after harvest (Table 2) probabily due to water loss (Allan-Wojtas, Forney, Carbyn \& Nicholas, 2001). Fruit firmness increased and this increase was delayed by 1-MCP application over the first few weeks of storage and then was quite stable until the end of storage period. After 7 and 14 days of cold storage, berries treated with 1-MCP showed firmness values of 22.9 D.I. and 21.3 D.I. while untreated fruit showed significantly higher firmness values (28.23 D.I. and 27.57 D.I.). On the contrary, at the end of storage, treated berries had the highest firmness values.

No significant effect of 1-MCP on fruit firmness was observed after 60 days CA storage, where treated berries showed firmness values of 33.2 D.I. and untreated of 33.8 D.I., in according with Rizzolo, Eccher Zerbini, Grassi, Cambiaghi and Binachi, 2006 in nectarines.

\subsection{Anthocyanin contents, phenolic contents, total antioxidant capacity}

In 2006, anthocyanin content at harvest was $8.8 \%$ higher than at harvest in 2007 (252.52 cyanidim 3glucoside). In general, total phenolics and total antioxidant activity are stable or increase during storage (Fawbush, Nock \& Watking., 2009). The results of this study indicate that antioxidant activity are relatively 
stable during air and CA storage and also the effects of 1-MCP on individual phytochemical groups were similar.

Berry fruit maintained high anthocyanin levels after 7 weeks of storage at $0^{\circ} \mathrm{C}$. In 2006 anthocyanin content was $17.5 \%$ (control) and $13.8 \%\left(1-\mathrm{mcp} 0.3 \mu \mathrm{l}^{-1}\right)$ higher at the end of storage than at harvest (fig. 1) but no significant effect of 1-MCP treatments was observed in 2006 and 2007 and also after CA storage.

The changes in anthocyanin content values over the postharvest period were also similar in trend to those for antioxidant activity. However for this parameter, in 2006, significant effect of 1-MCP treatment were detected after 7 and 28 storage days (fig. 2). In 2007, no significant effect of 1-MCP treatments on anthocyanin content was observed for either concentration, and also after CA storage period. The increase observed is due, probabily, simply to a higher concentration in fruit that has undergone water loss during storage. Increases in anthocyanin content during storage have been previously reported for lowbush blueberries (Kalt \& McDonald, 1996) and rabbiteye blueberries (Basiouny \& Chen, 1988).

In general, minor changes in total phenolics was measured between harvest and the end of storage (fig. 3). In 2006 significant lower total phenolic content were detected in 1-MCP samples after 14 days of storage. After CA storage, in according with anthocyanin and antioxidant values, no significant effect of 1-MCP treatments was observed in total phenolic content (fig. 3).

\subsection{Decay incidence}

Botrytis cinerea was the main fungus found on stored berries (Borecka \& Pliska, 1985; Ceponis \& Cappellini, 1985). The postharvest shelf life of blueberries is also limited by fungal decay.

The presence of pathogens was expressed as a percentage of decayed fruits and is show in Table 4. In 2006 losses for Botrytis cinerea was very low at the end of cold storage, also probabily due to high titratable acidity values (titratable acidity values >130meq/l) (Ballinger, Maness \& McClure, 1978). Morover, 1-MCP application had significant effect on decay incidence ( $0 \%$ incidence) compared to the control $(1.64 \%$ incidence). This results is probaby due also because the incidence of natural infection rate in this year was 
very low. The presence of this fungus coincides with that observed by Navarrete (2004) in rabbiteye blueberry 'Bonita', and Hevia et al. (2000) in red currant.

In 2007, the infection rate was higher. 1-MCP treatments reduced decay incidence only in the first three weeks of storage. The incidence of Botrytis cinerea in fruit treated with 0.3 and $0.6 \mu 11^{-1} 1-\mathrm{MCP}$ increased considerably with storage time (Table 3). After 60 days CA storage, 1-MCP reduced decay incidence in berries by $7.5 \%$ and $5 \%$, respectively, on exposure to 0.3 and $0.6 \mu 11^{-1}$ compared to the control.

\section{Conclusion}

1-MCP treatment at harvest controlled partially weight loss and decay development without undesirable changes in quality attributes, total sugars or acids after short and medium term cold storage. After long term CA storage, the beneficial effect of 1-MCP was limited on quality parameters and also on the incidence of Botrytis cinerea. Treated and control fruit tested demonstrated stability of antioxidant activity, total phenolic content, and anthocyanin content during cold storage. Thus, the health benefits from these berries can be retained well after harvest, until consumers eat them. In conclusion, the results suggests that 1-MCP could be useful only in controlling the weight loss of blueberry during storage period, but this result is too inconsistent to recommend the use of 1-MCP in commercial application.

\section{Acknowledgements}

We thank Dr Cucchi of AgroFresh Inc. at Rohn and Haas Italia for the gift of SmartFresh ${ }^{\text {SM }}$ (1-MCP 0.14\%).

\section{References}

Allan-Wojtas, P.M., Forney, C.F., Carbyn, S.E. \& Nicholas, K.U.K.G. (2001). Microstructural indicators of quality-related characteristics of Blueberries. An intergrated approach. Lebensmittel-Wissenschaft und-Technologie, 34 (1), 23-32. 
Almenar, E., Samsudin, H., Auras, R., Harte, B., Rubino, M. (2008). Postharvest shelf life extension of blueberries using a biodegradable package. Food Chemistry, 110, 120-127.

Ballinger, W.E., Maness, E.P. \& McClure, W.F. (1978). Relationship of stage of ripeness and holding temperature to decay development of blueberry. Jounal of the American Society for Horticultural Science, 103(1), 130-134.

Basiouny, F. M. \& Chen, Y. (1988). Effects of harvest date, maturity and storage intervals on postharvest quality of rabbiteye blueberries (Vaccinium ashei Reade). Processing of Florida State Horticultural Society 101, 281-284.

Blankenship, S.M. \& Sisler, E.C. (1989). 2,5-Norbornadiene retards apple softening. HortScience, 24, 313314.

Blankenship, S.M. \& Dole, J.M. (2003). 1-Methylcyclopropene: a review. Postharvest Biology and Technology, 28, 1-25.

Boquete, E.J., Trinchero, G.D., Fraschina, A.A, Vilella, F. \& Sozzi, G.O. (2004). Ripening of 'Hayward' kiwifruit treated with 1-methylcyclopropene after cold storage. Postharvest Biology and Technology, $32,57-65$.

Borecka, H.W. \& Pliska, K. (1985). Quality of blueberry fruit (Vaccinium corymbosum L.) stored under LPS, CA and normal air storage. Acta Horticulturae, 165, 241-249.

Cabezas, P. (2004). Calidad de frambuesa (Rubus idaeus L.) cv. Tulameen almacenada en atmósfera modificada. Tesis de Ingeniero Agrónomo. Universidad de Concepción, Facultad de Agronomía, Chillán, Chile.

Ceponis, M.J. \& Cappellini, R.A. (1985). Reducing decay in fresh blueberries with controlled atmospheres. HortScience, 20, 228-229.

Cheng, G.W. \& Breen, P.J. (1991). Activity of phenylalanine ammonia-lyase (PAL) and concentrations of anthocyanins and phenolics in developing strawberry fruit. Jounal of the American Society for Horticultural Science, 116, 865-869.

Colelli, G., D’Andria, F., Vanadio, S. \& Lacertosa, G. (2002). Prove di conservazione di uva (cv Italia) confezionata con film plastici. Italus Hortus, 9(4), 27-33. 
DeEll, J.R., Murr, D.P. \& Ehsani-Moghaddm b. (2008). Quality changes of "shiro" yellow plums in response to tretment with 1- methylcyclopropene. Jounal of Food Quality, 31, 514-525.

Dong, L., Lurie, S. \& Zhou, H. (2002). Effect of 1-methylcyclopropene on ripening of 'Canino' apricots and 'Royal Zee' plums. Postharvest Biology and Technology,. 24, 135-145.

Fan, X., Blankenship, S.M. \& Mattheis J.P. (1999). 1-Methylcyclopropene inhibits apple ripening. Jounal of the American Society for Horticultural Science, 124, 690-695.

Fawbush, F., Nock, J.F. \& Watkins, C.B. (2009). Antioxidant contents and activity of 1-methylcyclopropene (1-MCP)-treated 'Empire' apples in air and controlled atmosphere storage. Postharvest Biology and Technology, 52, 30-37.

Girardi C.L., Corrent A.R., Lucchetta L., Zanuzo M.R., da Costa T.S., Brackmann A., Twyman R.M, Nora F.R., Nora L., Silva J.A. \& Rombaldi C.V. (2005). Effect of ethylene, intermittent warming and controlled atmosphere on postharvest quality and the occurrence of woolliness in peach (Prunus persica cv. Chiripa) during cold storage. Postharvest Biology and Technology, 38, 25-33.

Hevia, F., Lanuza, P., Wilckens, R., Tello, M. \& Álvarez, D. (2000). Comportamiento de zarzaparrilla roja (Ribes rubrum) en almacenaje refrigerado y modificado. Agro Sur, 28, 42-50.

Kalt, W. \& McDonald, J. E. (1996). Chemical composition of lowbush blueberry cultivars. Jounal of the American Society for Horticultural Science 121, 142- 146.

Liguori, G., Weksler, A., Zutahi, Y., Lurie, S. \& Kosto, I. (2004). Effect of 1-methylcyclopropene on ripening of melting flesh peaches and nectarines. Postharvest Biology and Technology, 31, 263-268.

Loyola, N., Aranda, M., Teixidó, E.\& Palma, H. (1996). Empleo de envases físiológicos en frutos de arándanos para exportación. Agro Sur, 24, 113-125.

Miller, W., McDonald, R. \& Crocker, T. (1988). Fruit quality of rabbiteye blueberries as influenced by weekly harvests, cultivars, and storage duration. HortScience, 23, 182-184.

Navarrete, M. (2004). Arándano ojo de conejo (Vaccinium ashei Reade) cv. Bonita almacenado en atmósfera modificada. Tesis Ingeniero Agrónomo. Universidad de Concepción, Facultad de Agronomía, Chillán, Chile 
Pellegrini, N., Serafini, M., Colombi, B., del Rio, D., Salvatora, S. \& Bianchi, M. (2003). Total antioxidant capacity of plant foods, beverages and oils consumed in Italy by three different in vitro assays. The Journal of Nutrition, 133, 2812-2819.

Rizzolo, A., Eccher Zerbini, P., Grassi, M., Cambiaghi, P. \& Bianchi, G. (2006). Effect of 1methylcyclopropene on aroma compound in "Big Top" nectarines after shelf life. Journal of Food Quality, 29, 184-202.

Sisler, E.C. \& Serek, M. (1997). Inhibitors of ethylene responses in plants at the receptor level: Recent developments. Plant Physiology, 100, 577-582.

Slinkard, K. \& Singleton, V.L. (1977). Total phenol analysis: automation and comparison with manual methods. American Jounal of Enology and Viticulture, 28, 49-55.

Smittle, D.A. \& Miller, W.R. (1988). Rabbiteye blueberry storage life and fruit quality in controlled atmospheres and air storage. Jounal of the American Society for Horticultural Science 113, 723-728.

Trinchero, G.D., Sozzi, G.O., Covatta, F. \& Fraschina, A.A. (2004). Inhibition of ethylene action by 1methylcyclopropene extends postharvest life of "Bartlett" pears. Postharvest Biology and Technology, 32, 193-204.

Valero, D., Martinez-Romero, D., Valverde, J.M., Guillen, F., Castillo, S. \& Serrano, M. (2004). Could the 1-MCP treatment effectiveness in plum be affected by packaging? Postharvest Biology and Technology, 34, 295-303.

Wang, Z. \& Dilley, D. (2001). Aminoethoxyvinylglycine, combined with ethephon, can enhance red color development without overripening apples. HortScience, 36, 328-331.

Watkins, C.B. \& Miller, W.B. (2005). 1-methylcyclopropene (1-MCP) based technologies for storage and shelf-life extension. Acta Horticulturae, 687, 201-208.

Wills, R., B. McGlasson, D. Graham, \& Joyce D. (1998). Postharvest. An introduction to the physiology and handling of fruit, vegetables and ornamentals. 4th ed. 262 p. Hyde Park Press, Adelaide, Australia. 


\section{Tables}

Table 1

Weight loss (\%) in control and 1-MCP-treated lateblue blueberry during regular storage (RA) at $0^{\circ} \mathrm{C}$ and 90-95\% R.H.. Data are means of 3 replications.

\begin{tabular}{|c|c|c|c|c|c|c|c|}
\hline & & \multirow[b]{2}{*}{ treatment } & \multicolumn{5}{|c|}{ torage times (days at $0^{\circ} \mathrm{C}$ ) } \\
\hline & & & 7 & 14 & 21 & 28 & 35 \\
\hline \multirow[t]{2}{*}{2006} & weigth loss (\%) & control & $0.86 \mathrm{a}$ & $1.55 \mathrm{a}$ & $2.83 \mathrm{a}$ & $2.72 \mathrm{a}$ & $3.49 \mathrm{a}$ \\
\hline & & 1 -mср $0.3 \mu 11^{-1}$ & $0.83 \mathrm{a}$ & $1.31 \mathrm{~b}$ & $2.01 \mathrm{a}$ & $2.61 \mathrm{a}$ & $3.42 \mathrm{a}$ \\
\hline \multirow[t]{3}{*}{2007} & weigth loss (\%) & control & $2.05 \mathrm{a}$ & $2.83 \mathrm{a}$ & $3.12 \mathrm{a}$ & $3.78 \mathrm{a}$ & $4.4 \mathrm{a}$ \\
\hline & & 1 -mср $0.3 \mu 11^{-1}$ & $1.87 \mathrm{ab}$ & $2.64 \mathrm{a}$ & $3.04 \mathrm{ab}$ & $3.62 \mathrm{~b}$ & $4.22 \mathrm{a}$ \\
\hline & & $1-\operatorname{mcp} 0.6 \mu 11^{-1}$ & $1.72 \mathrm{~b}$ & $2.41 \mathrm{a}$ & $2.94 \mathrm{~b}$ & $3.58 \mathrm{~b}$ & $4.29 \mathrm{a}$ \\
\hline
\end{tabular}

Values for each parameters followed by the same letter within column (effect of treatment-mean or in each time) are not significantly different $(\mathrm{p} \leq 0.05)$. Means separated by Tukey’s test.

\section{Table 2}

Effect of 1-MCP on quality parameters (fimness, total soluble solid content, titratable acidity) during regular storage (RA) $\left(0^{\circ} \mathrm{C}, 90-95 \%\right.$ R.H.) and controlled atmosphere (CA) $\left(0^{\circ} \mathrm{C}, 90-95 \%\right.$ R.H.; $3 \mathrm{kPa} \mathrm{O} 2+11 \mathrm{kPa}$ $\mathrm{CO} 2)$. Means separated by Tukey's test. Means having different letters are significantly different $(\mathrm{p} \leq 0.05)$.

Data are means of 3 replications.

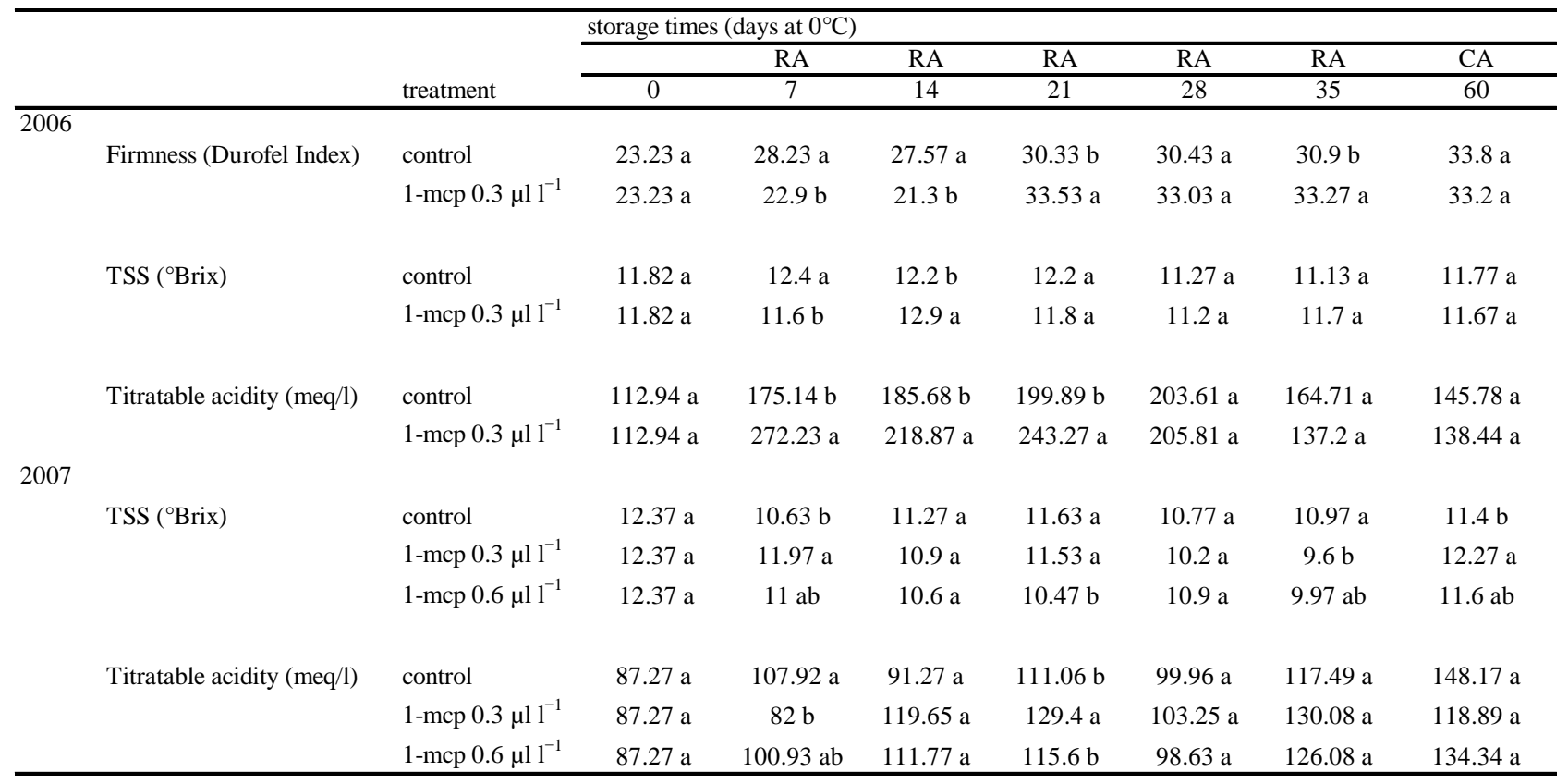


Table 3

Effect of 1-MCP on the incidence (\%) of Botrytis cinerea during regular storage (RA) $\left(0^{\circ} \mathrm{C}, 90-95 \%\right.$ R.H.) and controlled atmosphere (CA) $\left(0^{\circ} \mathrm{C}, 90-95 \%\right.$ R.H.; $\left.3 \mathrm{kPa} \mathrm{O}_{2}+11 \mathrm{kPa} \mathrm{CO}_{2}\right)$. Data are means of 3 replications.

\begin{tabular}{|c|c|c|c|c|c|c|c|c|}
\hline & & & \multirow{2}{*}{\multicolumn{6}{|c|}{ days at $0^{\circ} \mathrm{C}$}} \\
\hline & & & & & & & & \\
\hline & \multirow{2}{*}{\multicolumn{2}{|c|}{ treatment }} & RA & RA & RA & RA & RA & CA \\
\hline & & & 7 & 14 & 21 & 28 & 35 & 60 \\
\hline \multicolumn{9}{|l|}{2006} \\
\hline & \multirow[t]{2}{*}{ incidence (\%) of Botrytis cinerea } & control & 0 & 0 & 0 & 0 & 1.64 & 6.73 \\
\hline & & 1 -mcp $0.3 \mu 11^{-1}$ & 0 & 0 & 0 & 0 & 0 & 7.52 \\
\hline \multicolumn{9}{|l|}{2007} \\
\hline & \multirow[t]{3}{*}{ incidence (\%) of Botrytis cinerea } & control & 3.12 & 27.72 & 5.04 & 16.84 & 40.72 & 54.18 \\
\hline & & 1 -mcp $0.3 \mu 11^{-1}$ & 2.68 & 14.88 & 4.8 & 31.12 & 50.24 & 46.71 \\
\hline & & 1 -mcp $0.6 \mu 1 \mathrm{l}^{-1}$ & 4.64 & 10.6 & 7.8 & 23.56 & 34.8 & 49.06 \\
\hline
\end{tabular}

Figures

Figure 1

Effect of 1-MCP on anthocyanin content (mg/100g cyanidin 3-glucoside) during regular storage (RA) $\left(0^{\circ} \mathrm{C}\right.$, 90-95\% R.H.) and controlled atmosphere (CA) $\left(0^{\circ} \mathrm{C}\right.$, 90-95\% R.H.; $\left.3 \mathrm{kPa} \mathrm{O}+11 \mathrm{kPa} \mathrm{CO}_{2}\right)$. Means separated by Tukey's test. Data are means of 3 replications.

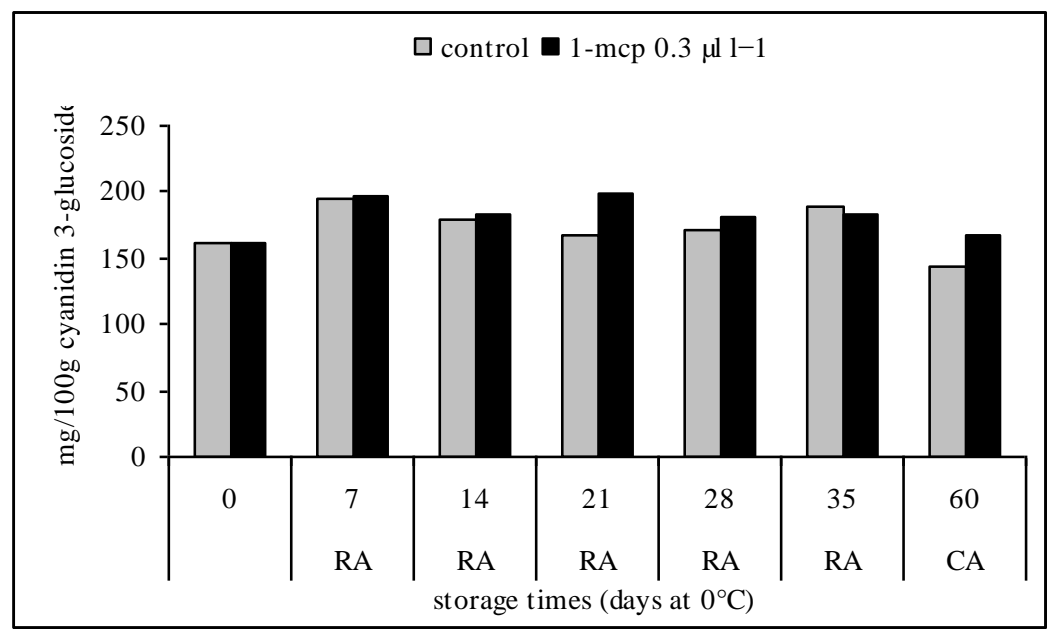


Figure 2

Effect of 1-MCP on antioxidant activity (mmol Fe2+/kg) during regular storage (RA) $\left(0^{\circ} \mathrm{C}, 90-95 \%\right.$ R.H.) and controlled atmosphere (CA) $\left(0^{\circ} \mathrm{C}, 90-95 \%\right.$ R.H.; $\left.3 \mathrm{kPa} \mathrm{O}+11 \mathrm{kPa} \mathrm{CO} 2\right)$. Means separated by Tukey's test. Means having * are significantly different $(\mathrm{p} \leq 0.05)$. Data are means of 3 replications.

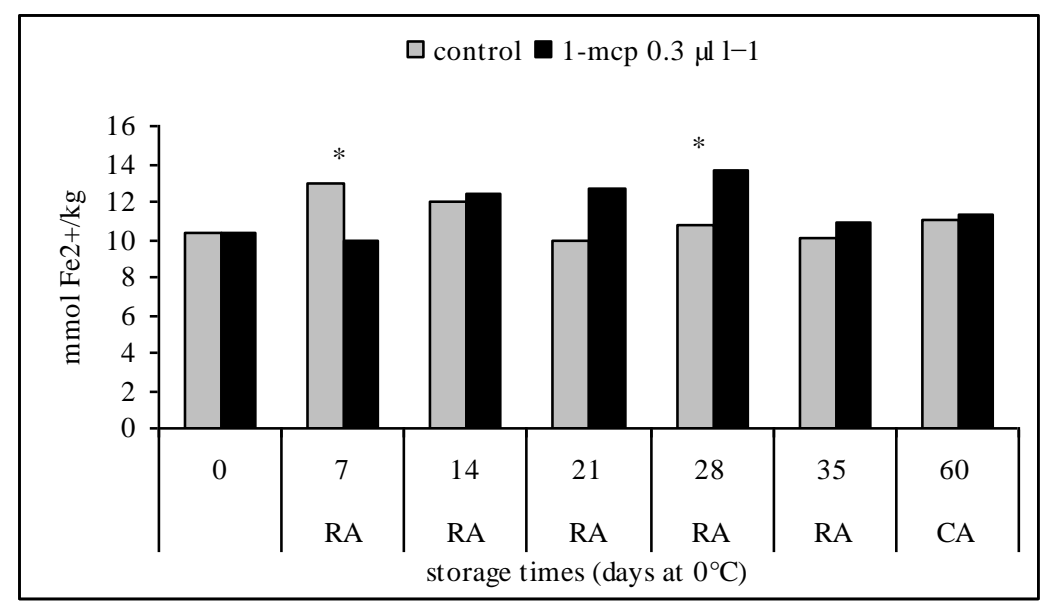

Figure 3

Effect of 1-MCP on total phenolic content (mg/100g gallic acid) during regular storage (RA) $\left(0^{\circ} \mathrm{C}, 90-95 \%\right.$ R.H.) and controlled atmosphere (CA) $\left(0^{\circ} \mathrm{C}, 90-95 \%\right.$ R.H.; $3 \mathrm{kPa} \mathrm{O}+11 \mathrm{kPa} \mathrm{CO}$ ). Means separated by Tukey's test. Means having * are significantly different $(\mathrm{p} \leq 0.05)$. Data are means of 3 replications.

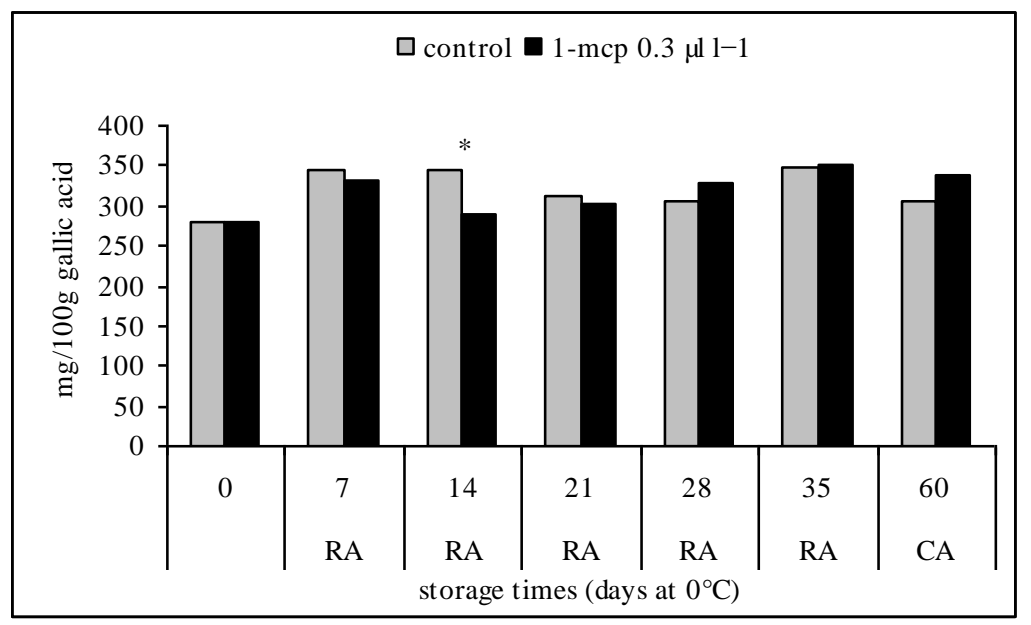

